\title{
IMPLEMENTATION OF TANK CLEANING AND LOADING AND DISCHARGING WITH SAFETY OF THE SHIP CREW OF MT FATMAWATI AT PT. BERLIAN LAJU TANKER
}

\author{
Asep Arif Bahtiar ${ }^{1}$, Juliater Simarmata ${ }^{2}$ \\ 1. STMT Trisakti, 2. STMT Trisakti \\ $\bowtie$ corresponding author: rizgelbahtiar@gmail.com
}

\begin{abstract}
The objective of the research is to analyze the influence of between tank cleaning and cargo loading and discharging activity with safety of the ship Crew on PT Berlin Laju Tanker, Type of research is quantitative research by means of survey, where the data obtained through a questionnaire that will be distribute on air to the ship Crew of PT Berlian Laju Tanker, The population in this research is a chemical ship Crew of PT Berlian Laju Tanker totaled 30, The sample taken is 30 (Nineteen) people. Data collected through the instrument in the form of questioner. Method of data analysis can be concluded that: (1) The tank cleaning has a positive and significant impact on safety of the ship Crew (2) The loading and discharging activity has a positive and significant impact on safety of the ship Crew (3) The tank cleaning and loading and discharging has a positive and significant impact on the safety of the ship Crew of MT Fatmawati on PT Berlian Laju tanker, The implication of the research are Safety of the ship Crew can be achieved and improve by upgrading the implementation the procedure of the tank cleaning and cargo loading and discharging and safety management system.
\end{abstract}

Keywords: Tank cleaning, Cargo loading and discharging, Procedure, Ship Crew safety, International Safety Code.

\section{Introduction}

Today the lack of progress and technological development in the field of chemical industry is very rapid, marked more and more of his kind of production of a chemical that is produced into raw materials and supplementary materials for the industries of manufacturing, such as plastics, synthetic rubber, cleaning agents, paint materials and supplementary material also other needs.

The increasing demand for liquid chemicals from year to year in various Asian regions is directly encouraging an increase in business in the field of cargo transportation of liquid chemicals. Shipping companies to anticipate the increase of haulage ship to build ships, especially chemical tankers. The tanker is one means of transport sea transport plays a role in transporting liquid cargo and oil. 
The development of science and modern technology today is very fast, then the tanker also was renewed so that in the unloading operations became more complex, Understanding the vessel according to Law No.17 of 2008 on the voyage, Article 1 number 36: The ship is a watercraft with certain forms and types, which are driven by wind power, mechanical power, more energy, withdrawn or suspended, including a powerful vehicle dynamic support, vehicles beneath the water surface, and floating equipment and floating structures that do not move.

To the crew working onboard the tanker is expected to overcome the problems encountered with the well and according to standard procedures that have been defined. In this case the loading and unloading on a chemical tanker ship cannot be separated with cleanup activities in tank. This is caused by the frequently changing load type. Cargo tank cleaning is a job that is important for a chemical tanker ship because prior to loading, the tank must be clean and ready to receive cargo to be loaded so that the charge is not damaged due to contamination, so it needs special care in preparing his tank. In the implementation of the loading and unloading MT. Fatmawati found several barriers that may impede the ship to dock to the terminals in the country of Indonesia. Therefore, for all tankers that will dock at the oil terminals there will always be inspected by a Marine inspector on the feasibility of ship in the implementation of the International Safety Management (ISM Code). (Muhammadiyah \& Majid, n.d.)

In the International Safety Management Code (ISM Code), (2003: 2) explained: "Means the International Management Code" for the Safe Operation of Ship and for Polution Prevention as Adopted by the Assembly, as may be Amended by the Organization and "Safety management system" means a structured and documented system enabling Company personnel to implement Effectively the company safety and environmental protection policy. Although the tanker is always loading and unloading at the same oil terminal should still be inspected by the safety officer or cargo surveyors who will examine the feasibility of tanks and safety equipment. The parties involved in the operation of the vessel at the time of loading and unloading 
activities need to take steps to anticipate delays when carrying out loading and unloading operation, until completion of the load and unload activity. The research objective was to determine the relationship of the activities of tank cleaning and cargo operation with the safety crew MT. Fatmawati PT Berlian Laju Tanker 2017. To find out whether if there is a delay of the process of unloading and cleaning tank can disrupt the system of supply chain management.

The problem is that the time execution of cleaning tanks often changes varies according to the type of content and level of difficulty of the process of cleaning the tank, so it will disrupt the process supply goods are ready for unloading.

Particularly in cargo tank laundering activity always gets attention deeper and more serious because of the implementation of which requires a long time, a lot of equipment, labor professional also the danger posed risks are enormous when things go wrong in practice. Realizing the dangers that threaten the lives and the pollution that caused the tanker at the time of operation, the most appropriate time to operate the washing tank is at the moment after unloading cargo.

Recognizing and knowing the importance of the role of washing tanks in tankers as one of the supporting safety to reduce the risk of accidents, either leak, fire or explosion during an operation, and therefore the use of these systems emphasize in regulation 62 chapter II-2 of SOLAS convention in 1974, and regulations as well as the usefulness of this system perfected again in the international convention in London on tanker safety and pollution prevention (TSPP) and the 1978 protocol as a new additional regulation 62 (a) requires that the inert gas system (IGS) should be planned, built and tested in accordance the provisions and meet IMO regulations. In this case the government is (IMO member) in which the vessel is registered Definition of tank cleaning is the process of wash the tank followed by procedures:

1. Machine wash the tank with Cold water

2. Flush all associated piping, heating coils and pump 
3. Thoroughly strip the tank of washings

4. Dry the tank trough ventilation and moping

5. Remove loose sediment, sludge and scale

(Hubber 2001:25)

The hazard of tank cleaning are Fire and explosion, undesired reaction, corrosion, overexposure, asphyxiation, emission, human injury, damage to the property, damage to the environment.

The relation between tank cleaning and Crew safety is the professionalism of the crew, understanding with operation of the tank cleaning procedure, Company procedure for tank cleaning, crew fatigue management, knowledge for each character of the cargo, Publication book guide and reference.

Human resource management according to Hasibuan (2007: 111) means that the preparation and implementation of a coordinated plan to ensure that human resources can be utilized as well as possible to achieve organizational goal, The following material management activities are activities that have mostly come from the scope of forwarding material management, including inventory control, purchasing, store keeping and forwarding. (Yunandyan, n.d.)

Loading and unloading activities are the activities of loading and unloading goods from or to the ship includes the unloading of the hold onto the dock at the ship's hull or vice versa (stevedoring), the activities of goods to dock in the hull into the barn yard or reverse it (cargodoring) and extraction of goods from the warehouse or field brought onto the truck or its reverse (receiving /delivery). (Decree No.KM.14.201 transportation minister, Section 1 of Article 1). "Loading-unloading activities are services activities engaged in loading and unloading activities and from ships, consisting of stevedoring activities, cargodoring, and receiving / delivery. The principle of loading and unloading must be carried by each crew in order to secure

a. Vessel protecting the vessel (the division of the charge in the vessel vertically and horizontally

b. Protect cargo from being damaged from loading until the demolition

c. Protect the crew and workers from the dangers of the charge 
d. Keeping the load carried on regularly and systematically

e. Implementation of stevedoring must be such that the smallest possible broken stowage.

Loading intent on doing regularly is (1). Prevent Long hatch, (2) Prevent over stowage, (3) Preventing Carried over. Types of loading and unloading equipment in tankers, among others: Cargo pump, connection or elbow, Cargo hose, Cargo monitor Level master, PV valve, and a few tools such as gas detector oxygen detector, $\mathrm{H} 2 \mathrm{~S}, \mathrm{CO} 2$. Some of the problems that often arise when loading and unloading as time wasted for carrying goods from the warehouse to the terminal, while preparing for loading and unloading equipment, labor is less capable, loading and unloading equipment that is less than perfect.

DA Lasse, (2006: 69-77) in his territorial environmental safety harbor cruise on to say that; "Maritime Safety influenced by internal factors vessel (engines, propellers, rudders, anchors, mooring lines, communication equipment) and external factors vessel (marine trafic, accessibility and tidal the length, width and shape of the river channel or canal, wind, currents and waves, weather, day and night, tugboats, and vessel traffic control system. (Lasse \& Darunanto, n.d.)

According to KM. 70 on manning (2008: 12): "crew are an absolute requirement for crew members who will work on board by meeting and having a certificate of seafarers (Certificate of Competence-COC) and certificates of special skills sailors (Certificate of Proficiency-COP ) ". In Act No. 17 of Article 1 on the voyage, (2008: 4): "The crew are working or employed on the ship by the owner or operator of the vessel to perform these tasks in accordance with his ship listed in the Crew list.

Regulations relating to occupational safety and health on board are as follows:

a. Constitution no. 1 Th. 1970 concerning safety of worker.

b. Ministerial Decree No. 4 of 1980 concerning the terms of installation and maintenance of fire extinguisher.

c. SOLAS 1974 and its amendments regarding vessel safety requirements. 
d. Amendment 1995 of the 1978 amanmend 2010 STCW training standards for seafarers.

e. ISM Code regarding the international management code for the safety of operation of ships and pollution prevention.

f. Occupational Health Th. 1950 concerning occupational health efforts. e.g international Code of Practice on the instructions - instructions on procedures / safety work on a piece of equipment, operation of ships and terminals.

g. Regulation of the Minister of Ttransportation of Indonesia PM No 70, 2013 concerning education and certification training and duty for seafarer

The quantity of human resources Indonesia not quite been able to make the handling of the maritime economy as a whole, although the quality can be tested and can be said to be no less than other human resource Country. (Lesmini, Purwanto, \& Trisakti, 1969)

\section{Method}

According Ridwan and Kuncoro (2010: 37) "Population is the unit of measurement of the characteristics or the research object or an object or subject population who are in an area and meet certain requirements related to the research problem". According Sugiyono (2013: 62) "The sample is part of the number and characteristics possessed by the population". Arikunto (2012: 117) The sample is part of the population Questionnaire is a technique of data collection is done by providing a set of questions or a written statement to the respondent to answer technique in the analysis of the data used by SPSS or Statistical Product and Service Solution is an application program that is used to perform statistical calculations using computer, the population and sample is 30 use the nonprobability sample with saturated sample, Types and Sources of Data The preparation of this paper the author uses descriptive method by giving descriptions. The data used is qualitative data with quantitative approach. That is by questionnaire and then numbering regarding the implementation of the activities of cleaning tanks and loading and unloading, crew safety, while the source of the data used is primary data source. With hypotesis there are relationship between tank cleaningoperation 
with safety of the crew, and cargo operation with safety of the crew altough the there are relationship between tank cleaning and cargo operation collectively with safety of the crew MT. Fatmawati. (Muhammadiyah \& Majid, n.d.)

The methods used to analyze are:

- Analysis of linear regression equation

- Analysis coefficients determinants

- Analysis hypothesis test

- Analysis the coefficient of correlation

\section{Discussion and Result}

a. The relationship between X1 (Tank cleaning) to Y (Safety Crew)

Based on the simple correlation calculation of analisis of coefiesien corelation $r=0.592$. it mean the relationship the implementation of the tank cleaning with safety of the crew is a strong and direct (positive), calculation of coefisient determination where in $\mathrm{r}^{2}=0.351$ or $35.1 \%$. the tank cleaning with crew safety by $35.1 \%$, Based on those that $\mathrm{t}$ count $>\mathrm{t}$ table or $3.888>1.701$ and $0.000<0.05$ means there is a strong positive correlation and significant implementation of the tank cleaning with crew safety, thus Hal research hypothesis is accepted, The results of data processing to the overall statement of the respondent in the variable implementation of the cleaning tank shows that the lowest weight in a statement to the eighth and tenth with the highest weight in the first to the statement and an average weight of 4.45 so that it can be said that the implementation of the cleaning tank PT Berlian laju tanker is good enought and has a significant positif impact and positif with the safety of the crew MT Fatmawati.

b. The relationship between X2 (Cargo operation) with Y (Ship crew safety)

c. From the simple correlation calculation $r=0.763$. From these results, it appears that the relationship cargo operation with safety crew is strong and direct (positive), by looking at the calculation wherein $\mathrm{R}$ square of 0.582 
or $58.2 \%$. This shows the magnitude of the contribution cargo operation relationship to safety crew by $58.2 \%$, Based on those that $t>t$ table or $6.246>1.701$ and $0.000<0.05$ means there is a strong positive relationship significant and cargo operation with the safety crew, thus $\mathrm{Ha} 2$ research hypothesis is accepted, and show that the relationship between cargo oepration and crew safety of the MT fatmawati are significant and positif impact.

d. The relationship between X1 (Tank cleaning) and X2 (Loading and unloading operation) collectivety with $\mathrm{Y}$ (Ship crew safety)

Obtained from the calculation of multiple correlation $r=0.766$. From these results, it appears that the relationship implementation of tank cleaning and cargo operation with safety crew is strong and direct (positive), By looking at the above calculation where in square of 0.587 or $58.7 \%$. It shows the contribution of activity implementation relations tank cleaning and cargo operation with crew safety by $58.7 \%$, Regression X1 and X2 to $\mathrm{Y}$ (doubles), $\mathrm{Y}=12.101+0,083 \mathrm{X} 1+0,621 \mathrm{X} 2$, Based on those that $\mathrm{F}$ count> $\mathrm{F}$ table or $19.168>3.354$ means there are multiple significant correlation implementation of tank cleaning and cargo operation with Crew safety, thus Ha3 research hypothesis is accepted

\section{Conclusion}

Results from this reseach is that there is a positive relationship and strong between the activities of tank cleaning (X1) and loading/discharging (X2) operation with Crew safety, meaning the activities of tank cleaning effect on crew safety in the presence of the linear regression equation of 0.083 which implies that every the increase in the activities of tank cleaning 1 unit will be followed by a rise in safety crew of 0.083 units and vice versa if decreasing, same thing also with loading and discharging activity that affects greatly to the safety of the crew, amounting to 0.621 which means that any increase in cargo loading and discharging 1 unit will be followed by the increase crew safety by 0.621 units and vice versa if decreaseing, based on the questionare have been given to the sample that the safety of the crew can be improve and 
achieved and improve by upgrading the implementation the procedure of the tank cleaning, additional the time frame for tank cleaning, and cargo operation and by implementation of safety management system between ship and shore management.

\section{References}

D.A. Lasse (2007). Management Peralatan, Jakarta: Nika

Di, K., Pelayaran, P., \& Edi, D. W. (n.d.). Keseimbangan antara disiplin kerja dan kompensasi dengan produktivitas kerja karyawan di perusahaan pelayaran, 390-404.

Hasibuan ( 2007). Manajemen Sumber Daya Manusia, cetakan kesembilan, Jakarta : PT Bumi Aksara Huber, (2001).Marine Biology, Fifth edition. The Mc Graw Hill Companies

International Safety Management Code (ISM Code), (2003:2) International convention in London on tanker safety and pollution prevention (TSPP) 1978, article 62

Keputusan Badan Diklat Perhubungan Indonesia No.434/DL.002/ Diklat2000 tentang Kurikulum Pendidikan Profesional Kepelautan Dan Pendidikan Tehnis Fungsional Kepelautan (2000:4): tentang kelaiklautan awak kapal

Keputusan Menteri Perhubungan Indonesia No. KM 14 Tahun 2002, Bab 1 Pasal 1, tentang kegiatan bongkar muat

Lasse, D., \& Darunanto, D. (n.d.). BAGI ANAK BUAH KAPAL, 257-266.

Lesmini, L., Purwanto, B., \& Trisakti, S. (1969). Ekonomi Maritim \& Sumber Daya Manusia Indonesia, 372-389.

Ministerial Decree of workers Indonesia No. 4 of 1980 concerning the terms of installation and maintenance of fire extinguisher

Muhammadiyah, U., \& Majid, S. A. (n.d.). Formulasi Kebijakan Sistem Policy Formulation of Sea, 3(2), 161-183.

Regulation of the Minister of Ttransportation of Indonesia PM No 70, 2013 concerning education and certification training and duty for seafarer.

Sugiyono, (2011). Metode Penelitian Bisnis, Alfabeta, Bandung.

SOLAS ( Safety of life at sea ) 1974, about Ship safety requriment

STCW (Standards of Training, Certification and Watch keeping for Seafarers) 1978 amandment 2010

Undang-undang No 1 Th. 1970 tentang keselamatan pekerja Undang-undang Nomor 17 Tahun 2008 Tentang Pelayaran Pasal 1 ayat 36. 